\title{
A Pensadora Negra em Educação Petronilha Beatriz Gonçalves e Silva: Memórias e Reflexões
}

\author{
SILVA, Claudilene Maria da ${ }^{1}$ \\ DIAS, Lucimar Rosa ${ }^{2}$ \\ VALENTIM, Silvani dos Santos ${ }^{3}$
}

\section{RESUMO}

O presente texto retoma questões relevantes sobre o pensamento negro em educação no Brasil. Por meio desta entrevista aprofundamos como 23 anos depois da publicação do livro que inaugurou os debates a esse respeito, as questões sobre o pensamento negro brasileiro coerentemente reverberam, desafiam e interpelam a Educação das Relações Étnico-Raciais no alvorecer do século XXI. Profa. Petronilha afirma que tal pensamento veio com os povos Negros africanos escravizados e que na Diáspora foram sendo recriados e refeitos, particularmente por meio das experiências dos/as professores/as negros/as, especialmente das professoras negras, durante todo o século XX. Foram destacados durante a entrevista elementos como a relevância e atualidade de uma práxis pedagógica antirracista e propostas do movimento Negro, das instituições Negras e dos projetos e pesquisas que assumem um compromisso visceral e dialógico com a história e perspectiva do povo Negro. Por meio de suas memórias familiares e escolares a entrevistada nos lembra que, por mais escolarizadas/os que sejamos, não podemos prescindir do pensamento que é construído nos núcleos familiares, nas comunidades, nos espaços religiosos de matriz africana e pelo movimento Negro. É importante ter presente que existe um pensamento Negro em educação em todas as áreas da vida. Ainda que importantes organizações do movimento Negro tenham se articulado nos anos 1970, é anterior a este período a formulação do pensamento Negro em educação. Este pensamento antecede o movimento Negro organizado como nós o conhecemos. Ele foi, de fato, iniciado pelas professoras Negras do antigo Ensino Primário, hoje Ensino Fundamental.

\footnotetext{
${ }^{1}$ Doutora em Educação pela Universidade Federal de Pernambuco. Professora da Universidade da Integração Internacional da Lusofonia Afro-Brasileira (UNILAB) - Campus dos Malês /Bahia. Coordenadora do curso de pedagogia do Campus dos Malês - São Francisco do Conde - Bahia. E-mail: claudilenems@unilab.edu.br. Lattes: http://lattes.cnpq.br/5637844544469243. Orcid: https://orcid.org/0000-0003-1015-1251. 2 Doutora em Educação pela Universidade de São Paulo (USP). Professora da Universidade Federal do Paraná (UFPR). Coordenadora do ErêYá - Grupo de Estudos e Pesquisas em Educação Para as Relações Étnico-raciais (ERER). E-mail: lucimardias1966@gmail.com. Lattes: http://lattes.cnpq.br/3476684741346049. Orcid: http://orcid.org/0000-0003-1334-5692.

${ }^{3}$ PhD. em Educação, Temple University, USA. Professora do Centro Federal de Educação Tecnológica de Minas Gerais (CEFET-MG). Pesquisadora do CNPq e Coordenadora o projeto de pesquisa Afrociências no (CEFET-MG). E-mail: silvanisvalentim@gmail.com. Lattes: http://lattes.cnpq.br/8274357459966258. Orcid: http://orcid.org/0000-0002-5798-2477.
}

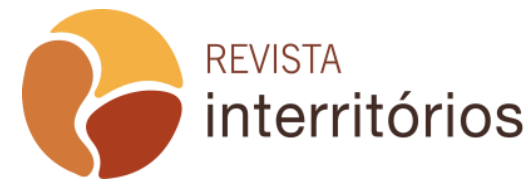

Interritórios | Revista de Educação Universidade Federal de Pernambuco, Caruaru, BRASIL | V.6 N.12 [2020] 
Educação. Pensamento Negro. Professoras Negras. Movimento Negro.

\author{
The Black Thinker in Education Petronilha \\ Beatriz Gonçalves e Silva: memories and reflections
}

\begin{abstract}
This text takes up relevant questions about black thought in education in Brazil. Through this interview we went on to deepen how 23 years after the publication of the book that inaugurated the debates in this regard, questions about Brazilian black thought consistently reverberate, challenge and question the Education of Ethnic-Racial Relations at the dawn of the 21st century. Professor Petronilha affirms that such thought came with the enslaved African Black people and that in the Diaspora they are being recreated and remade, particularly through the experiences of Black teachers, especially Black female teachers, throughout the 20th century. Elements such as the relevance and timeliness of an anti-racist pedagogical praxis and proposals from the Black movement, Black institutions, projects and research that assume a visceral and dialogical commitment to the history and perspective of the Black people were highlighted during the interview. Through her family and school memories, the interviewee reminds us that, no matter how schooled we are, we cannot do without the thought that is built in family nuclei, in communities, in religious spaces of African base and by the Black movement. It is important to keep in mind that there is a Black thought in education in all areas of life. Although important organizations of the Black movement were articulated in the 1970s, the formulation of Black thought in education predates this period. This thought precedes the organized Black movement as we know it. It was, in fact, initiated by Black teachers from Primary School, today known as Elementary School.
\end{abstract}

\title{
Education. Black Thought. Black Teachers. Black Movement.
}

\section{La pensadora negra en la educación Petronilha Beatriz Gonçalves e Silva: memorias y reflexiones}

\section{RESUMEN}

Este texto retoma cuestiones relevantes sobre el pensamiento negro en la educación en Brasil. A través de esta entrevista pasamos a profundizar cómo 23 años después de la publicación del libro que inauguró los debates al respecto, las preguntas sobre el pensamiento negro brasileño reverberan, desafían y cuestionan consistentemente la Educación de las Relaciones Étnico-Raciales en los albores del siglo XXI. Profa. Petronilha afirma que este pensamiento llegó con los negros africanos esclavizados y que en la Diáspora fueron recreados y rehechos, particularmente a través de las experiencias de los maestros negros, especialmente los maestros negros, a lo largo del siglo XX. Durante la entrevista se destacaron elementos como la relevancia y actualidad de una praxis

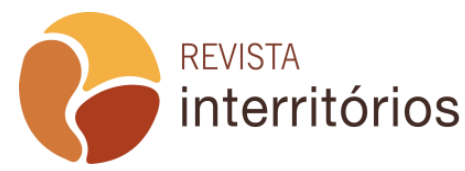


pedagógica antirracista y propuestas del movimiento negro, instituciones y proyectos negros e investigaciones que asumen un compromiso visceral y dialógico con la historia y perspectiva de los negros. A través de sus recuerdos familiares y escolares, la entrevistada nos recuerda que, por muy escolarizados que estemos, no podemos prescindir del pensamiento que se construye en los núcleos familiares, en las comunidades, en los espacios religiosos de origen africano y por el movimiento negro. Es importante tener en cuenta que existe un pensamiento negro en la educación en todos los ámbitos de la vida. Aunque en la década de 1970 se articularon importantes organizaciones del movimiento negro, la formulación del pensamiento negro en la educación es anterior a este período. Este pensamiento precede al movimiento negro organizado tal como lo conocemos. De hecho, fue iniciado por profesores negros de la antigua Escuela Primaria, hoy Escuela Primaria.

Educación. Pensamiento negro. Maestros negros. Movimiento negro.

\section{La pensatrice di educazione Petronilha Beatriz Gonçalves e Silva: ricordi e riflessioni}

\section{SOMMARIO}

Questo testo riprende questioni rilevanti sul pensiero nero nell'educazione in Brasile. Attraverso questa intervista siamo passati ad approfondire come 23 anni dopo la pubblicazione del libro che ha inaugurato i dibattiti a questo proposito, le domande sul pensiero nero brasiliano riverberano, sfidano e mettono in discussione costantemente l'Educazione alle Relazioni Etnico-Razziali all'alba del $21^{\circ}$ secolo. Profa. Petronilha afferma che questo pensiero è venuto con i neri africani ridotti in schiavitù e che nella diaspora sono stati ricreati e rifatti, in particolare attraverso le esperienze di insegnanti neri, specialmente insegnanti neri, per tutto il XX secolo. Durante l'intervista, sono stati evidenziati durante l'intervista elementi come la rilevanza e la tempestività di una prassi pedagogica antirazzista e proposte dal movimento nero, istituzioni e progetti neri e ricerche che assumono un impegno viscerale e dialogico per la storia e la prospettiva del popolo nero. Attraverso i suoi ricordi familiari e scolastici, l'intervistata ci ricorda che, per quanto scolarizzati, non possiamo fare a meno del pensiero che è costruito nei nuclei familiari, nelle comunità, negli spazi religiosi di origine africana e dal movimento negro. È importante tenere presente che c'è un pensiero nero nell'educazione in tutti gli ambiti della vita. Sebbene importanti organizzazioni del movimento negro siano state articolate negli anni '70, la formulazione del pensiero negro nell'educazione è anteriore a questo periodo. Questo pensiero precede il movimento nero organizzato come lo conosciamo. Fu, infatti, iniziato da insegnanti neri della ex scuola elementare, oggi scuola elementare.

Istruzione. Pensiero nero. Insegnanti neri. Movimento nero.

\section{INTRODUÇÃO}


Apresentar a nossa entrevistada, a professora Petronilha Beatriz Gonçalves e Silva não é tarefa fácil, pois tem em seu currículo inúmeras possibilidades. Por isso, destacamos o fato de que ela é professora Emérita da Universidade Federal de São Carlos. Fez parte do Núcleo de Estudos Afrobrasileiros desta instituição. Pesquisadora das relações étnico-raciais, práticas sociais e processos educativos, políticas curriculares e direitos humanos. É doutora pela Universidade Federal do Rio Grande do Sul, UFRGS, mesmo estado em que nasceu, se licenciou em Letras e Francês e durante a entrevista pediu que não esquecêssemos de dizer que ela é gaúcha, nascida em Porto Alegre e viveu sua infância no bairro Colônia Africana.

Representou a comunidade cientifica negra em diversos espaços institucionais. Pertence a Ordem Nacional do Mérito, no Grau de Cavaleiro, em reconhecimento de sua contribuição à educação no Brasil (2011). É integrante do Conselho do Amiru Shonghoy Hassimi O. Maiga, chefe do Povo Songhoy, no Mali (2010). Tem inúmeros textos publicados, orientações realizadas e traz em sua bibliografia um marco importantíssimo foi a primeira mulher negra a ter assento no Conselho Nacional de Educação na Câmara de Educação Superior do Conselho Nacional de Educação (2002-2006) e protagonizou a relatoria do Parecer CNE/CP 3/2004 que estabelece as Diretrizes Curriculares Nacionais para a Educação das Relações Étnico-Raciais e para o Ensino de História e Cultura Afro-brasileira e Africana. Um dos documentos mais importantes do campo educacional, que sem dúvida expressa de modo contundente o que acumulamos acerca do Pensamento Negro em Educação.

A professora Petronilha é seguramente uma das mais importantes representantes do Pensamento Negro em Educação na contemporaneidade e nos brinda nesta entrevista com suas memórias, sua história de vida, apresentando estratégias de resistência que professoras negras de sua infância (especialmente sua mãe) desenvolviam em suas vivencias educativas para garantir às crianças negras a permanência e o avanço na escolarização. As palavras de Petronilha nos colocam a pensar, o que mais e como fazer para avançar no projeto educacional antirracista e nos indaga sobre a contribuições do Pensamento Negro em Educação para a Educação Brasileira. Com a palavra:

\section{Entrevista com a professora Petronilha Beatriz Gonçalves e Silva}

Professora Petronilha gostaríamos de agradecer muito o seu aceite ao nosso convite para esta entrevista. Esta edição da Revista Interritórios, que estamos organizando tem como tema "Pensamento Negro e Educação no Contexto Afrodiásporico". Então, consideramos importante ouvi-la. A ideia é retomar a discussão sobre um Pensamento Negro em Educação no Brasil, 23 anos depois da publicação do livro que marcou os debates a esse respeito tendo como organizadoras, a senhora e a professora Lúcia Maria de Assunção Barbosa. 
Naquele momento a pergunta que orientou o livro e o seminário que produziu a publicação, foi:Como o Movimento Negro interpreta o processo educativo do seu povo? É a partir desse mote que nós gostaríamos de conversar. Existem novos elementos que constituem esse pensamento em educação?

Eu não sei se eu consigo responder. A pergunta é bastante profunda. Eu creio que sim porque tanto o pensamento como os processos educativos, que têm a ver com esse pensamento negro, eles se põem, e se recompõe, se fazem e se refazem nos momentos históricos e políticos. É importante a gente ter sempre presente que esse pensamento foi sendo construído, particularmente por professoras negras que estavam com as crianças pequenas. Eram essas professoras que as apoiavam. Quero dizer com isso que as professoras, sobretudo, as professoras primárias (etapa na qual estavam a maior parte das crianças negras) fortaleciam as crianças. Faziam o combate ao racismo. Eu fiz o ginásio no Colégio de Aplicação da Faculdade de Filosofia da UFGRS. Éramos durante o ginásio três meninas negras. Depois, a partir do colegial, o secundário em diante... Eu fui sempre a única pessoa. Tanto menina ou menino ou mulher ou homem negro. É bom lembrar que durante o século passado, sobretudo ... Até mais da metade do século passado as crianças negras eram em minoria nas escolas, sobretudo, nas escolas a partir do secundário. A partir daí, praticamente as professoras negras não estavam mais presentes.

Não havia professores que fizessem o que elas faziam. Ficando mais a cargo da família. Isso penso em relação à minha própria experiência. A minha mãe foi professora. É importante dizer isso. Na minha época de ginásio era frequente ter um trabalho livre que a gente podia escolher o tema e escrever sobre ele, ilustrar, enfim... Sempre que tinha trabalho livre, a minha mãe me propunha que fizéssemos sobre a história do povo negro, sobre cultura negra. $\mathrm{E}$ assim, quando se tratava de obras que eram mais complexas, que eu poderia não entender ela marcava o que eu podia ler. Mas, tinha que ler no livro, como ela me dizia e depois dizer com as minhas palavras. Isso era um modo de produzir um pensamento em mim, ainda criança a partir da nossa cultura. Ela fazia isso comigo e eu sei de outras professoras amigas dela que também realizam este trabalho. Então o pensamento negro em educação vem muito antes do movimento negro organizado como nós conhecemos. Ele foi iniciado pelas professoras negras primárias.

Professora, na sua opinião, atualmente tem outros elementos do Pensamento Negro em Educação que não foram discutidos quando vocês lançaram o livro? 
Olha eu realmente acho uma pergunta difícil. Eu quase que eu teria que folhear o livro agora... Nesse momento, o que penso que não estava lá e está no presente... Eu penso que agora temos maior presença de pessoas negras em todos os níveis de ensino. Não unicamente nos anos iniciais ou até o ginásio como acontecia. Conforme eu já disse na minha experiência de infância, por exemplo. No primário eu morava num bairro que se chamava Colônia Africana. Não era o nome oficial, mas era assim que era conhecido e vocês imaginam o motivo. Nós éramos na escola primária um número de crianças negras bastante grande. No ginásio, nós éramos três meninas. E no colegial para a frente, eu passei a ser a única pessoa. Esse quadro modificou bastante.

Com frequência eu lembro quando eu era menor talvez antes de entrar para o primário, ou logo nos meus primeiros anos, a minha mãe como eu já disse era professora. Ela lecionava num bairro distante aqui em Porto Alegre, então ela lecionava para um número de estudantes negros maior do que das escolas mais centrais. Naquela época quem concluía o quinto ano fazia formatura. Era uma formatura solene. Com a presença do prefeito da cidade, porque para muitas crianças ali terminava o tempo de estudos e ingressavam no mundo do trabalho. Era uma formatura com direito a ganhar o certificado, enroladinho como se fosse um diploma, todo mundo vestido muito bonito. Eu lembro da minha mãe dizer em uma delas em que foi paraninfa e foi uma coisa que me chamou a atenção. Ela disse: "desejo que vocês tenham muito sucesso. Que o vocês aprenderam ajude na continuidade dos estudos e para aqueles que não forem continuar estudando e já forem trabalhar...", ou seja, lá no final dos anos 40 era mais ou menos comum que crianças aos 10, 11 anos, já ingressassem no trabalho. Por isso, acho importante dizer que muito do que a gente pode construir hoje, a gente deve as professoras negras. As professoras negras lá nas escolas... Quando eu digo professoras, não estou deixando os professores de fora, é porque eles eram raros na escola primaria.

As professoras era que orientavam e protegiam as crianças de alguma forma. Minha mãe e suas amigas negras falavam que as crianças negras, muitas vezes, não tinham material de estudo: o caderno, borracha, lápis, enfim. Lembro que minha mãe dizia que quando notava que uma criança tinha terminado 0 caderno e ela percebia que não havia condições de vir outro caderno. Ela fazia um sorteio de caderno. Era assim para caderno, lápis, borracha, material escolar. E nestes sorteios sempre quem ganhava era quem estava precisando. Ela não dava diretamente para a criança para proteger a dignidade. Para todos, a criança tinha sorte e por isso ganhava no sorteio.

As professoras negras usaram muitas estratégias de proteção e orientação às crianças negras. Eu conheci uma professora, essa em São Paulo, mais ou menos da faixa da minha mãe que me contou que morava perto da escola onde trabalhava e as crianças que ela notava que tinham dificuldade de aprendizagem eram convidadas por elas para vir até sua casa para ajudá-la em 
alguma atividade doméstica, mas de fato não era para ajudar em nada. Era para ela pudesse possibilitar aquela criança o que a gente chama hoje de reforço escolar. Então ela dizia: "ah eu preciso de alguém que me ajude com o meu jardim". E quando a criança chegava na casa dela falava: "ah já foi feito o que eu precisava no jardim, mas vamos ver como é tu estás na leitura... ou com as contas". E com isso ela dava o reforço escolar.

Outra coisa que me lembro é de duas amigas da minha mãe que lecionavam na escola em que eu estudava. No primário quando eu fiz o primário havia três turnos... Das $8 \mathrm{~h}$ às $11 \mathrm{~h}$, das $11 \mathrm{~h}$ às $14 \mathrm{~h}$ e das $14 \mathrm{~h}$ às $17 \mathrm{~h}$. As crianças que estudavam das $11 \mathrm{~h}$ e as $14 \mathrm{~h}$ eram estigmatizadas. As repetentes. Essas professoras negras lecionavam, justamente neste horário. E eu perguntava para minha mãe... Porque que elas dão sempre aulas, das $11 \mathrm{~h}$ às $14 \mathrm{~h}$ ? E a mãe dizia assim: "Elas têm muita paciência, são muito hábeis". E realmente elas conseguiam fazer aquelas crianças avançarem. Sendo um bairro de maioria ou de um número significativo de negros é claro que no turno das $11 \mathrm{~h}$ às $14 \mathrm{~h}$ muitas crianças eram negras.

A senhora está a apresentar, de uma forma fascinante suas memórias de professora. Está a falar sobre estratégias que professoras negras, incluindo a sua própria mãe, utilizavam para a permanecia, engajamento das crianças negras. Nessa época também acontecia no Brasil, toda uma movimentação na constituição do movimento negro. Abdias Nascimento e todas as questões que a senhora tão bem conhece. Sendo assim como é que a senhora compreende o pensamento negro? Essas estratégias que aconteciam no chão da sala de aula, no miúdo, no cotidiano, no dia a dia da vida das professoras têm alguma relação, algum diálogo ou influência com este movimento negro?

Olha eu penso que sim, talvez não fosse explicitado para todo mundo. Era quase que um acerto entre a professora e seus alunos. Isso eu estou dizendo olhando de fora. Todas nós somos professoras e já fomos de crianças menores ou maiores. A gente sabe que tem alguns vínculos que se fazem inclusive com troca de olhares, um gesto carinhoso. Emprestar uma borracha, por exemplo: "Olha a borracha da professora". Para a criança que não tem. Penso que há um vínculo sim. A presença da professora negra para a criança negra é importante. Dou um exemplo: uma vez, eu acho que já estavam no ginásio. Nós éramos conforme eu disse, poucas. Éramos três meninas negras. Um dia a professora resolve dizer que o meu nariz era grego. Acho que talvez me branqueando, me enaltecendo. "Tu tens um nariz grego". Eu cheguei em casa com essa novidade: "Mãe a professora disse que eu tenho um nariz grego". Minha mãe respondeu: "Que esperança! Teu nariz não é grego de jeito nenhum é egípcio. Teu nariz é parecido com o da rainha Nefertiti". Não era qualquer nariz!!! vocês estão vendo? Ela foi atrás de uma figura da Nefertiti para me mostrar. "Tá vendo aqui, o nariz

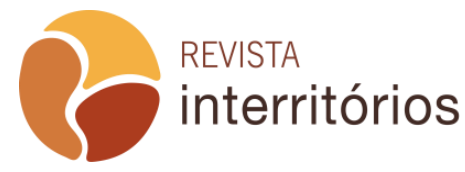


da rainha Nefertiti? Teu nariz é igual o dela. Então tu tens que dizer para professora que teu nariz não é grego, que teu nariz é egípcio".

Professora, relacionado os textos que vocês produziram no seminário sobre Pensamento Negro em Educação, com meus estudos tenho chamado de Pensamento Negro em Educação esse conjunto de ideias e de práticas educativas que foram sendo construídas pelos ativistas ou pelas organizações do movimento negro, com a intenção de prover uma educação de qualidade para população negra. A senhora considera possível ampliar essa definição? Como a senhora definiria o Pensamento Negro em Educação atualmente?

Este pensamento não vem dos ativistas. Ele vem das professoras negras e dos professores negros. E os ativistas contavam com a presença dessas professoras nas escolas. Por exemplo, em São Paulo o grupo do Abdias, anteriormente nos anos 20 em São Paulo ou mesmo aqui no Rio Grande do Sul, quando os grupos negros, as associações negras, a sociedade negra se reuniam, eles contavam também com a presença das professoras. Embora naquela época os homens aparecessem mais, as professoras estavam sempre presentes.

Será que as professoras negras contemporâneas têm essa mesma forma de ação?

Depende da professora. Como deveria também depender das professoras negras anteriormente. Eu respondi tendo como base a minha experiência com a minha mãe e com as amigas dela que eram negras também. Eu acredito que sim. Sim e não. Porque tem aquele problema de identificação, que talvez exista cada vez menos. No sentido de que algumas pessoas acham que se assumir, assumir a sua negritude que não está exposta na pele, nem no aspecto físico é uma forma estar fora do universo do pensamento da educação, fora da produção de conhecimento. É não se sentir trazendo uma contribuição genuína.

É um esforço muito grande de educação das famílias, das escolas de valorização das diferentes contribuições para a nação brasileira. Porque até hoje muitos brasileiros reconhecem fundamentalmente a raiz europeia e tem o desejo de ser o mais europeu possível, ou se parecer o mais europeu possível. Se não podem fisicamente, vão tratar de fazê-lo no pensamento. Isso quer dizer que o nosso olhar está ainda virado demais para o Hemisfério Norte e não a partir de experiência de Hemisfério Sul, incluindo os europeus que por aqui estão, ou melhor dizendo dos descendentes de europeus que muitas vezes têm um sentimento de serem mais humanos, não vou nem dizer mais brasileiros. Porque eles descenderiam de povos que a sociedade em geral valoriza mais ou valoriza

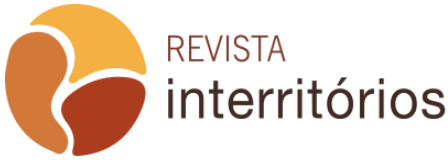


como superior. Eu sempre digo, os europeus têm uma autoimagem muito positiva, o que é muito bom. Mas, é importante que todos nós tenhamos uma autoimagem muito positiva e que possamos dialogar com as nossas positividades. E que nós negros, indígenas, ciganos precisemos nos impor, não no sentido ser superior, mais no sentido de ser respeitado, conhecido e compreendido... É uma luta. É uma luta permanente. O descredito já começa pela cor da pele, pois quando olham para nós, já acham que não devemos ser quem a gente é ou quem possamos ser.

Então, penso que é importante que nós professores negros e professores não negros tenhamos o cuidado, a intenção de expor esse pensamento, de mostrar de onde vem este pensamento que a gente tem sobre educação. De mostrar que por mais escolarizados que sejamos, a gente não abre mão do pensamento que é construindo nas nossas famílias, nas comunidades e pelo Movimento Negro também. É importante salientar que o movimento negro é dos anos 1970, não é aí que começa se formular um Pensamento Negro em Educação. Ele é muito mais antigo, em educação formal. E produzido por professoras negras, especialmente.

Professora, como a senhora avalia o processo político. Esse caminho que colaborou para a construção das normativas antirracistas conquistadas: a Lei 10.639/03, CNE/CP 3/2004. Como a senhora avalia essa trajetória dos movimentos, do pensamento negro e sua influência nas normativas. Eles estão realmente presentes no sistema de ensino?

Eu espero que estejam. Espero que estejam e a gente tem trabalhado por isso, assim como os professores e as professoras sobretudo durante todo o século $\mathrm{XX}$, trabalharam neste sentido. Nós que tivemos ou estamos ainda no sistema de ensino trabalhamos neste sentido. Hoje trazemos até como objeto de estudo: quais são as raízes do que nós formulamos como pensamento negro? Eu lembro que quando o livro foi lançado uma pessoa não negra quando leu o título entendeu que eram pensamentos negativos, que negros eram pensamentos negativos em educação, coisas horríveis que se pensava em educação. Eu tive de explicar para ela que não. O negro aqui é de gente negra, de gente que pensa, de descendentes de africanos que formula pensamento em educação.

Isso mostra que ainda depende dos professores negros, explicitarem este pensamento, não só nas suas falas e seus textos, mas no seu comportamento, na relação com os estudantes negros, sem esquecer os outros, é claro. Mas fazer os estudantes negros se sentirem fortalecidos. Um dia discutindo na graduação em pedagogia na Federal de São Carlos, essa questão de as pessoas menosprezarem aquilo que elas não conhecem ou aquilo que foi ensinado a elas que devem desprezar, e como isso produzia sofrimento para as crianças, particularmente às crianças negras ou as que tivessem alguma deficiência. $\mathrm{E}$

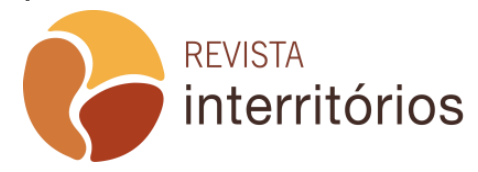


assim por diante... E de repente uma aluna se levanta na aula e começa a falar com muita veemência dizendo: "professora não são só as pessoas negras ou as pessoas com deficiência aqui nesse estado, também os nordestinos. Nesta universidade a cada dia, há pessoas, não todas, mas há pessoas que procuram me mostrar que este não é meu lugar."

Professora Petronilha, a senhora destacaria elementos da experiência das professoras negras que influenciam o pensamento negro e o pensamento nacional brasileiro? Também, elementos do pensamento negro, que influenciam o pensamento nacional e a nação brasileira e passam a ser utilizados não só na educação, mas em outras áreas das Ciências Humanas e Sociais, por pesquisadoras/es das mais diversas áreas. Quais são as contribuições advindas da educação, que vão se abrindo e atingindo outros campos, outros lugares, outras pessoas?

Eu acredito que esse pensamento ele se constrói a partir da relação das professoras negras com seus alunos, negros e não negros. É do convívio entre as professoras. A raiz dele está na experiência das pessoas negras, enquanto negras. Das professoras negras, com suas famílias, a vizinhança, a comunidade, com quem convivem e dessa forma se vai construindo de uma maneira conforme disse, anteriormente, numa relação entre professora e alunos, na sala de aula ou intercambiável entre professoras.

Conforme já mencionei a minha mãe tinha amigas, claro professoras, mas algumas dessas amigas eram amigas negras e eram professoras negras. E elas se reuniam. Não me lembro nunca de reunião formal, do tipo: "Vamos fazer um congresso e tal". Mas, elas se reuniam para festejar, se reuniam para tomar um chá. E conversavam, contavam as vezes situações de racismo, davam muita risada. Uma vez uma dessas professora que era até professora do Grupo Escolar onde eu estudava que era amiga contou um fato que ocorreu com ela. As professoras naquela época se vestiam muito bem. Elas se distinguiam pela forma de vestir. Ela disse que estava no centro da cidade e uma senhora branca veio na direção dela e perguntou: "tu queres trabalhar na minha casa?" E ela respondeu: "Olha eu posso. Se a senhora me pagar o dobro do que eu estou recebendo atualmente". E a senhora se entusiasmou e disse: "mas quanto tu estás recebendo?" Ela disse o quanto ganhava e a pessoa disse: "mas tu estás louca? Por que é que eu vou pagar tudo isso por uma empregada doméstica?" e a professora responde: "Olha, o trabalho não me interessa, estava me interessando o salário. Hoje eu sou professora do Estado do Rio Grande do Sul. Eu recebo tanto, se a senhora me pagar o dobro eu vou ser empregada doméstica". E a senhora é claro ficou muito sem jeito. Lembro muito até hoje dá risada que ela e as amigas negras deram contando este fato.

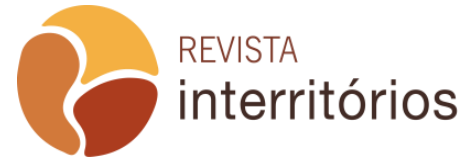


Eu diria que há pessoas, colegas professores que são sensíveis. Sensíveis às relações entre pessoas. E que são sensíveis a um projeto de sociedade. Em que todos sejam igualmente incluídos e que uns não tenham que tentar impor seus pontos de vista, o seu jeito de ser, ou a sua raiz cultural e que outros não tenha que estar sempre na defensiva se impondo. Então tem esses aliados que não só apoiam, mas acolhem. Penso que o que está em discussão é o projeto de nação que a gente tem e o projeto sociedade que queremos. Se é um projeto em que todas as pessoas, independentemente do seu jeito de ser, de viver, do seu pensamento, da sua origem étnico-racial são igualmente importantes. Todos têm de ser igualmente valorizados e compreendidos. Eu sempre disse, sobretudo, para os estudantes que estranhar o outro, o diferente de mim não é ofensivo. Porque eu estranho tudo o que é diferente de mim. Eu conheço sempre a partir de mim. Eu tenho como referência para conhecer o mundo, para me pôr no mundo, aquilo que eu recebi como educação e aquilo que me faz pessoa. Mas, eu não sou o centro do mundo. Nós todos somos o centro do mundo. Tem de ser parte dessa minha formação a disposição e a vontade para compreender o outro, o diferente de mim. Então, posso estranhar um ponto de vista, posso estranhar um gosto, mas eu não posso desprezar diminuir e querer impor o meu ponto de vista. Ora a escola, as escolas nascem justamente pela imposição de um ponto de vista europeu. A escola é uma criação europeia. E ela entra nos diferentes continentes como um aporte que vem da Europa como o mais importante, o mais rico e o mais humano.

Aqui no Rio Grande do Sul lá na época da colonização havia povos indígenas e os jesuítas procuraram convencer os estudantes que a forma como seus familiares construíam casas não era boa e que a forma de construir casas boas eram como os europeus construíam. A forma de vestir não era uma forma também humana. A gente conhece as outras pessoas, as outras culturas a partir de nós mesmos. Mas, quem foi que disse que somo o melhor e o centro do mundo? Penso que esse é um dos grandes objetivos da educação das relações étnico-raciais no meu entender. Só posso conhecer a partir daquilo que eu sou, daquilo que eu aprendi, do que eu me formei e a convivência vai me dar outras referências, que eu posso aceitar ou não aceitar, que eu posso incorporar ou não incorporar, sem deixar de ser o que eu sou.

A escola nasce na Europa e chega até nós a partir do pensamento de que tudo que está na escola é o melhor, o mais importante e às vezes até o mais humano. A grande pergunta essa: como eu posso valorizar igualmente os diferentes aportes da cultura brasileira, sem desvalorizar nenhum? Como eu valorizo igualmente? Por isso é importante ter presente que existe um Pensamento Negro em Educação em todas as áreas da vida. Existe, mas foi menosprezado. Então aquele nosso esforço lá, nos anos 90 foi um esforço de dizer isso. Ao ler o livro que publicamos sobre o tema vemos que os autores fizeram um esforço também sustentado no movimento negro. O que eu quero 
dizer é que essa postura e este esforço são anteriores ao movimento negro. Mas, o movimento negro começa a sistematizar e a dar o suporte para essas formas de pensar. Não são mais professoras isolados sozinhas produzindo seus modos de pensar. Tem um suporte que vem da sociedade, que vem do grupo étnicoracial. Eu não estou dizendo que o movimento negro está tomando o lugar dos professores não é isso. Ele está dando referência para os professores negros. No livro mencionado, tem um artigo da Nilma Lino Gomes em que ela diz que o movimento negro bateu às portas, os portões da escola e entrou. Então... 0 movimento entrou enquanto movimento. Nós negros estávamos lá representados pelas professoras negras.

Muito interessante esta ponte que você faz entre a produção do pensamento negro em educação realizado pelas professoras negras muito antes do movimento negro se instituir como ator social. Nesse sentido para você como o Pensamento Negro em Educação dialoga com a tese da profa Nilma Lino Gomes tão brilhantemente formulada do movimento negro como educador. Qual é esse diálogo?

Eu até ampliaria um pouco, no sentido de entender que os movimentos sociais são educadores. Para que cada movimento social educa a sociedade? Porque a ideia que muitas pessoas têm é de que um movimento social faz reivindicações, talvez seja, o que mais apareça, mas ao fazer a sua reivindicação o movimento social está educando. Educando a sociedade no sentido de fazer compreender que não existe um segmento dessa sociedade mais importante, mais bonito ou superior, ou seja, existem outros que têm igual importância, que também pensam, que também tem propostas. E nós que estamos na educação somos chave para que estes pensamentos e as proposições dos diferentes movimentos estejam presentes, que eles dialoguem perguntando o que nós temos em comum e que escola nós queremos construir. Esse é um movimento chave. Se nós tivermos presente que escola nós queremos? Que escola brasileira nós temos que fazer, daqui para a frente, não estou negando tudo 0 que se fez até hoje, estaria negando inclusive a minha tarefa de professora. Mas, com o que nós temos, o que nós queremos daqui para frente? E ao fazer essa pergunta, estamos também fazendo outras ou tentando responder a outras... Que sociedade que queremos? Qual é o projeto de sociedade que as nossas aulas, o nosso sistema de ensino está propondo? Para quais projetos de sociedade nós trabalhamos? Claro, os movimentos sociais dão essa resposta, eu penso. E nós, com o nosso ensino, nós também damos essa resposta. Seja na forma como nós estabelecemos a relação professor e aluno, seja nos textos que a gente leva para ler e discutir, seja nos procedimentos de avaliação, seja na valorização que nós damos para a palavra do aluno, para a postura do aluno, para a contribuição que o aluno possa trazer a partir da sua experiência e valorização da sua própria experiência. 
Como diria minha amiga Vera Triunfo, quando ela gosta de uma coisa ela é diz que é muito bonito! Eu acho muito bonita nossa profissão nesse sentido. Ela se constrói no convívio e com diferentes aportes. Assim o Pensamento Negro em Educação pode trazer ou tem trazido, um aporte importante para essa relação de quem ensina e quem aprende, quem aprende e quem ensina, porque de fato sabemos que não é só uma forma de dizer. Quem ensina antes de ensinar teve de aprender e depois que ensinou também aprendeu porque os alunos, os estudantes também trazem o seu retorno e com eles a gente aprende. Seja com a pergunta, seja com comportamento, ou seja, com o silenciamento. Por isso, é importante incentivamos as respostas criativas dos estudantes e não simplesmente a repetição. O que eles constroem, porque estudar é construir. Claro, vamos construindo a partir do que outros antes construíram. Mas, estudar não é repetir o que os outros disseram antes, sem decodificar, sem ler a partir da própria perspectiva. Isso é complicado, em termos de avaliação tal como se processam até hoje. Mas eu acho que essa é uma contribuição que talvez se possa ainda dar. O que seria a avaliação do ensino aprendizagem nas escolas, nas universidades, a partir do Pensamento Negro em Educação? Quais contribuições nós temos para avaliação? E consequentemente se é para a avaliação, para o processo de ensino aprendizagem? O que faz o nosso ensino diferente?

Professora Petronilha a senhora traz a ideia de diálogo e o diálogo em Paulo Freire não é só fala. É fala, escuta, mas é também ação. Há contribuições do Pensamento de Paulo Freire no Pensamento Negro em Educação?

Eu diria que tem um vaivém. O Paulo Freire tem a influência de Amílcar Cabral, entre outros. Vivemos numa sociedade em que nós trazemos diferentes pertencimentos, o que significa diferentes visões de mundo, compreensão das relações entre as pessoas, formas de formular o pensamento. Talvez a grande contribuição que nós temos é no sentido de pôr em diálogo. Por em diálogo sem deixar de ser o que a gente é. Porque a educação escolar justamente enraizada na Europa, que vem da Europa colonizadora que se pretende trazer como centro do mundo. Claro cada um de nós se vê como o centro do mundo. Mas, já passou da hora da gente entender que se cada um se vê o centro do mundo. Temos diferentes centros que tem que ser postos em conversa. Conversar mesmo. Eu gosto da palavra conversa porque ela vem assim como algo que eu ponho junto. Aquilo que cada um esparrama de si, porque quando eu falo eu me esparramo diante dos outros e os outros se esparramam diante de mim. Então a gente põe esta "esparramação" juntos. É isso que dá conversa. 
Professora como a senhora avalia os diálogos entre o pensamento negro em educação no Brasil, como o pensamento negro em outros contextos Afrodiásporico?

Eu penso que eles ainda são reduzidos. No meu entender. Então fica difícil de avaliar. Eu posso dizer a partir da minha experiência e ela diz respeito com os Estados Unidos, muito pouco com a Colômbia, que nós temos de aprofundar, particularmente, não unicamente. Com a África do Sul e minha experiência mais recentemente foi com Moçambique, juntamente com o pessoal da Universidade Federal do Maranhão, que tem um trabalho antigo e profundo e eu tive a oportunidade, de no ano passado ficar com eles quase um mês convivendo, trocando ideias, criando laços. Aliás, não diria criando, diria apertando os laços. Eu penso que é importante buscarmos estas trocas. Hoje temos meios, estamos distantes é verdade e tem as questões de fuso horário, mas grava-se. É importante não só entre nós, é claro, mas também entre os estudantes. No sentido de ir muito além daquela valorização que se dá ao intercâmbio internacional. Isso é muito mais do que um intercâmbio internacional.

Assim quando eu penso a experiência com a Joyce King nos Estados Unidos, e depois com Hassimi Maiga no Mali, foi algo muito rico. São oportunidades de trocas quando ambos os lados têm curiosidade e desejo de compreender o outro. $O$ outro que também é um afro, mas que é um afro diferente. E nos ajuda a pensar o que podemos juntos construir. Isso vai além de intercâmbio de pesquisa, dos textos que nós fazemos e os congressos que nós participamos. Penso que é uma atitude de disposição para compreender. Porque somos todos negros, mas somos todos diferentes, no Brasil mesmo, Norte ao Sul, Leste a Oeste, Centro Oeste. Somos diferentes. E isso é bom, não é ruim a diversidade humana faz parte do humano. Agora, a gente vem de uma escolarização de raiz europeia que parte da imposição de um ponto de vista, da imposição de uma visão de mundo, como se isso fosse o centro do processo educativo. Eu penso que a grande contribuição do Pensamento Negro é dizer que existem outras formas de ver e situar no mundo e que são igualmente valiosas. Como a gente põe em diálogo essas diferenças? Nossas experiências de educação ainda frequente é a da imposição. É claro que a gente fala a partir de Paulo Freire em diálogo, temos que dialogar e tal. Mas, nos falta ainda no meu entender construímos realmente esse diálogo, porque a construção do diálogo prevê o respeito. Eu não posso dialogar, se eu não respeito porque eu vou ou impor a minha posição ou vou me submeter a posição do outro. Agora se tiver sido convencida eu não me submeti eu acolhi, o que é diferente.

Então, é uma oportunidade que nós pensemos e vocês que estão ainda mais frequentemente com a mão na massa, com os estudantes sobre: quais são as nossas contribuições para a educação brasileira? Eu não diria só do movimento negro. Contribuições de professores negros e evidentemente nessa 
contribuição de professores negros está presente o movimento negro. Quais são as contribuições de professores negros para a educação brasileira? Quem sabe até para uma didática afro-brasileira que possa ser justamente aceita, admitida e dialogada com uma didática euro-brasileira, e com uma didática indígena brasileira? Talvez esse seja um ponto importante pensarmos: quais contribuições trazemos para a educação? Acredito que uma contribuição nossa é o acolhimento. A forma que a gente acolhe os estudantes. E esse acolher não é paparicação, ou pode ser também, mas é a forma como olhamos, como perguntamos. Sabemos perfeitamente que a troca de olhares entre professor e aluno é chave na aprendizagem. Como pergunta, como aceita a resposta?

Alguém uma vez me disse: "poxa qualquer coisa que a gente diga a senhora ouve com tanta curiosidade". Fiquei pensando que os professores também me ouviam com muita curiosidade, principalmente, uma professora de história lá no ginásio. Tinha 11 anos. A Dona Elita, falecida há muitos anos, qualquer coisa que um aluno dissesse, tu tinhas a impressão quando falava diante dela, que tu estavas trazendo a maior descoberta da humanidade, porque ela tinha uma abertura, uma disposição para te ouvir. Acho que aprendi isso com ela e trouxe para a minha relação professora aluno que foi muito mais tarde construída. Ouvir com atenção e curiosidade, o que a outra pessoa tem a dizer. Concordando ou discordando, mesmo que depois vá discutir ou não acolha. Essa relação é importante, a disposição para ouvir o outro e esperar que o outro tenha à disposição para me ouvir. Porque a gente nem sempre concorda, felizmente. O conhecimento não só de uma pessoa ou de outra, mas o conhecimento que a gente tenta ensinar se produz entre concordâncias e discordâncias.

Nós temos um último pedido: Qual seria a mensagem de resistência, luta e esperança que a senhora enviaria para as/os educadoras/es, pesquisadoras/es e integrantes dos movimentos negros na educação e na sociedade brasileira?

É importante persistir e persistir no sentido não de teimosia, mas persistência no sentido de insistir com as nossas raízes. Não como as mais importantes, mas como uma das importantes. E a difícil tarefa de pôr em diálogo. É difícil porque para fazer isso a gente tem que justamente mostrar que a gente vem de uma nação que foi construída com imposição de muitas coisas sobre outros inclusive como formas de pensar e forma de se educar. E que isso não serve mais. Aliás nunca serviu e há muito tempo não serve. Para a construção que nós podemos fazer trazemos a contribuição da raiz africana. Os euro-descendentes, dos eurodescendentes, os indígenas, dos indígenas. E quais construções fazemos juntos? Somos capazes realmente de nos pôr em diálogo? Porque eu sempre insisti com os meus estudantes no seguinte, eu me espanto ou discordo de alguma coisa que é muito diferente de mim. A minha tendência primeira, a nossa

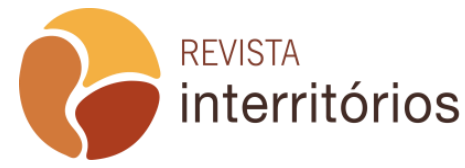


tendência de pessoas é que ser centrado em si mesmo, querendo ou não. Mas o fato de sermos centrados em nós mesmos é que nos dá condições de nos pôr em diálogo e não em imposição. Dialogar não é impor meu ponto de vista, mas mostrar de onde parto, ouvir, acolher ou não acolher, debater. E sempre que a gente sai de uma conversa não saímos igual. Essa é a troca. Isso é o importante. Essa é uma contribuição fundamental do Pensamento Negro em Educação. $O$ pensamento negro na educação não é um pensamento impositivo ele é acolhedor. E a partir deste acolhimento, construtor. O que nós construímos juntos? Mas como a gente vem de uma tradição, inclusive de escolarização que se impõe... É uma construção ainda difícil. Vocês que estão com a mão na massa devem saber o quanto difícil é...

Como a senhora como a senhora quer ser apresentada nesta entrevista?

É uma questão de educação. O nome é cumprido, não importa. Alguém uma vez reclamou e minha mãe disse: "isso é para dar trabalho para quem escreve!" Então, o meu nome inteiro. Gaúcha, professora, pesquisadora das relações étnico-raciais. Alguém que tem tido a sorte de conviver com pessoas como vocês, com outros que vieram antes e tem tido a possibilidade de conversar com pessoas, de conviver e elaborar com pessoas. Algumas pessoas fora do país o que dá uma referência importante para a nossa negritude. Não estamos sós! Não estamos sós e construímos juntos. Eu acredito que nós tenhamos enquanto pessoas negras, a partir da nossa experiência, não só a nossa experiência atual, mas da experiência de um povo que foi escravizado. Foi desterrado. É uma experiência que tem que ser sim, trazida por os escravizadores e seus descendentes querem esquecer. Nós não queremos que seja esquecido não para a vingança, não. Porque só quando nós assumirmos essas nossas diferentes experiências e dolorosas é que elas vão ser realmente superadas e nós vamos ter condições de criar uma sociedade que seja realmente respeitosa, democrática e que valorize os nossos diferentes pertencimentos e as nossas diferentes contribuições. Penso que se vocês me perguntarem de onde vem o Pensamento Negro, eu digo que ele veio com os escravizados. E aqui ele foi sendo criado, recriado e refeito. As experiências dos professores negros, notadamente das professoras negras, durante todo o século $X X$, desde o início, as experiências e propostas veementes do movimento negro e hoje das pesquisas realizadas, principalmente por pessoas negras, homens e mulheres que veem a perspectiva do povo negro. Acredito que seja por aí e por muito mais porque só eu falei, não ouvi vocês e tenho certeza têm muitas outras coisas a dizer a partir de suas experiências.

\section{REFERÊNCIAS}


GOMES, Nilma Lino. O movimento negro educador: saberes construídos nas lutas por emancipação. Petrópolis, RJ: Vozes, 2017.

SILVA. Petronilha Beatriz Gonçalves e. BARBOSA. Lucia Maria de Assunção. (orgs). O Pensamento Negro em Educação no Brasil. São Carlos: Ed. UFScar, 1997. 